\title{
The Insecurity State: Punjab and the Making of Colonial Power in British India
}

Review Number: 2228

Publish date: Thursday, 22 March, 2018

Author: Mark Condos

ISBN: 9781108418317

Date of Publication: 2017

Price: $£ 75.00$

Pages: 270pp.

Publisher: Cambridge University Press

Publisher url: http://www.cambridge.org/gb/academic/subjects/history/south-asian-history/insecurity-state-punjab-a making-colonial-power-british-india?format=HB\#U5X4JSZJ1KUC02B1.97

Place of Publication: Cambridge

Reviewer: Michael Philipp Brunner

Next year will mark the centenary of one of the most extreme and brutal displays of colonial power and violence, the so called Amritsar Massacre of 1919. The massacre took place in a public park called Jallianwala Bagh in the city of Amritsar where British Indian army's Colonel Reginald Dyer on 13 April 1919 ordered his troops to fire on unarmed protestors gathered there. According to the official (but disputed and probably too conservative) account of the British Indian government, 379 people died and 1200 were wounded on this day, and the event often is seen as a turning point in the history of British rule and its legitimacy on the subcontinent. Coincidently, this violent act of oppression happened in the British Indian province of Punjab. In the historiography on British India, it is a commonplace that the Punjab was the 'Garrison State', characterised by its (in)famous authoritarian school of administration and the home of various loyal 'martial races' filling the ranks of British India's military forces that in the imperial imagination would secure the stability of the British Raj.

The massacre at Jallianwala Bagh also functions as the introductory point of Mark Condos' The Insecurity State: Punjab and the Making of Colonial Power in British India. In his book, however, Condos sets out to reassess the image of Punjab and to analyse the province's authoritarian system of governance and its impact on British India not from the perspective of colonial strength but vulnerability and insecurity, revealing what he calls the 'dark underside' of colonialism which he locates in a deeply seated colonial culture of insecurity and fear. Dealing with the actions and thoughts of British colonial administrators, Condos claims that it was 'a pervasive and constant sense of anxiety, vulnerability and uncertainty about the survival of the colonial regime' (p. 220) that lay at the base of the colonial experience of the British rulers.

The Insecurity State consists of five main chapters that, although sometimes overlapping in their narratives, are arranged in chronological order. Chapter one outlines the first 100 years of military and territorial expansion of British rule in India with a focus on the North West of the subcontinent, from the consequential Battle of Plassey in 1757 to the 'Mutiny' of Indian soldiers in the services of the East India Company in 1857. The chapter also functions as an introduction to one of the key arguments of Condos; that the British through the whole of their rule on the subcontinent felt this rule to be one of a tiny minority of white colonial 
administrators surrounded by potentially hostile native subjects. As Condos shows, this feeling was reiterated and cultivated in a 'culture of insecurity' that eventually became fundamentally ingrained in the Anglo-Indian mind by the traumatic experiences of the rebellion of 1857 .

The second chapter describes the 'pacification' of Punjab after its annexation into British India in 1849 and particularly the process of integrating the Sikh soldiers of the defeated Sikh Empire into a colonial Punjab. As Condos argues, concerns about the alleged 'warlike' nature of the recently subjected people at the new north-western frontier of British India drove the Punjab administrators to seek a relationship both patronising and patriarchal with native groups deemed 'martial races', such as the Sikhs. While this integration was achieved quite successfully through the exceptional recruitment of these groups into the colonial military as well as schemes that favoured and established them as agriculturists, the chapter emphasizes the persistence of fears among the administrators that these 'domesticated' martial groups still might rebel someday against their colonial masters. This fear and its consequences are exemplified by Condos in the last part of the chapter where he deals with the Punjab Disturbances of 1907, an agrarian unrest that had sprung up after the introduction of the controversial 'Punjab Colonization of Land Bill', and the authorities' reaction to this.

A specific event and its legal and public aftermath are discussed in the third chapter of the book, namely the outbreak and violent suppression of the so called 'Kooka uprising' of 1872, when revolting Sikhs from the Namdhari sect threatened colonial authority. Tracing first the origins of the famous 'Punjab school' of governance that was characterized by giving local officials much autonomy and extensive administrate and juridical powers and by its reticence to processes of legal codification in British India in the second half of the 19th century, it then sketches out in detail the events of 1872. The following section analyses how the local and provincial authorities came to react in rather panicky ways to the in fact quite small uprising of bands of radical Sikhs. It shows how the ensuing administrative and public debate oscillated between concerns about the on-going process of legal codification (and the consequential moral legitimacy of colonial rule) and the veneration and defence of the Punjab style of administration that allowed the "men on the spot' to preserve their sovereignty in an environment deemed exceptionally hostile and fragile.

The fourth chapter then deals with the history of a particular piece of legislation, the 'Murderous Outrages Act' (MOA) of 1867. It considers its implementation, reception and subsequent adaption for other oppressive acts of legislation. Preceded and influenced by the Moplah Act of 1854, the MOA was a reaction to reoccurring assassinations of and attacks on frontier officials at the North-Western Frontier. It granted British officials extensive rights to try subjects whom the act deemed 'fanatics' outside of the normal legal purview. Two aspects of the legislation and its debate are further elaborated by Condos. The first is the contemporary debate on whether the burning of the bodies of these often Muslim 'fanatics' was an acceptable measure to show to potential attackers the grave consequences they would face should they be tried, or whether such an act would go too far and undermine the moral legitimacy of the empire in the eyes of its subjects. Secondly, the chapter analyses how the 'fanatic' actually was defined in these acts, concluding that is was the elusive and ambiguous definition of the term that made the act the powerful tool it was. Finally, Condos traces the reception of the Act and shows how it reverberated up to the late phase of the British Raj when the MOA Act and similar legislation became heavily attacked by Indian nationalists.

The thesis' final chapter returns to the topic of military and police recruitment, but this time deals not with service in Punjab and the Indian army but looks at the popularity of Punjabi servicemen in overseas police and military forces. It analyses attempts to regulate this movement of persons by Indian authorities who were motivated by both a fear of losing potential recruits for their own services and imperial security concerns as Punjabis started to enlist also in the services of foreign powers and even imperial rivals such as the Germans or Russians. The severe anxieties these foreign-employed Punjabis caused among British India's officials sees Condos manifested in their reactions to the so called Ghadar Movement during the First World War. The Ghadar Movement, a revolutionary movement comprising of mostly Punjabis living in North America, among them many Sikhs and (ex-)soldiers, was made possible by the formation of transnational networks and inter-imperial mobility. Condos argues that, in an atmosphere fuelled by exaggerated fears that went way beyond the actual reach into Punjabi society the Ghadar Movement had, it 
was the authoritarian Punjab administrative ethos and the lobbying of Punjab officials in response to the Ghadar threat, rather than revolutionary activities in Bengal as previously had been stressed, that led to the notorious Defence of India Act in 1915. In the Ghadar movement Condos, thus, sees a prime example of a pattern he stresses throughout the book, namely that anxiety drove the British administrators to cultivate Punjab as a bastion of imperial security, but that its results (recruitment of Punjabis, fostering of agricultural classes, etc.) eventually came back to them as threats causing further anxieties.

The individual chapters of The Insecurity State differ quite a lot in terms of pace, scope and cogency. Whereas chapter one makes anxiety to a large extent the motor of British imperialism, chapter three uses the concept to explain the actions of particular persons on a particular occasion. Unfortunately, not all these accounts are equally convincing. This has to do to a big extent with the term (or concept) of 'anxiety' that Condos puts in the foreground of his argument. It is only a small argumentative step from stating that 'security concerns' cause authoritarian legislation to stating that 'anxieties' cause authoritarian legislation. Yet the argument (and to some extent originality) of Condos' book relies mostly on the distinction that the motivation of the British officials described in The Insecurity State was not 'mere' security concerns but founded on specific 'anxieties'. Unfortunately, despite being the crucial term in his study, what 'anxiety' actually means as an analytical term and how it qualifies as something different than varying political concerns and personal fears, remains rather vague.

There are a few possible qualifiers of 'anxiety' that occasionally do show through in the individual chapters of the book, for instance irrationality/emotionality, a disparity between subjective and objective concerns, and the perpetuity and deep-rootedness of these insecurities. However, Condos himself counters these readings and attributes. While the introduction especially dwells on the subjectivity of these colonial anxieties, the individual case studies show that the officials often were driven by concerns that were hardly imaginary. In the book's conclusion the author presents us with a synthesis that highlights the heterogeneous reasoning and intentions that underlay the policies, attitudes, and episodes described in the book's various chapters. According to Condos, British officials' fears (or: anxieties) were mostly neither mere emotional overreactions nor deliberate fabrications, and officials did assess the possible effects of their actions and policies. The book's conclusion offers a balanced analysis of imperial fears, oppressive actions/reactions and legal debates, but coincidently it also partially undermines Condos' stress on the relevance of distinct 'anxieties'. What Condos is successfully able to show through his emphasis on 'anxieties' is that British officials could draw on a shared memorial culture of fear of rebellion which helped legitimize their actions whether they were spontaneous or calculated. Still, the argument of the book and the analytical relevance of its key term could have been more persuasive if the author had elaborated more on what the often-referred-to 'anxiety' actually means. This could have been accomplished, for example, through a more explicit engagement with the quickly growing field of the history of emotions - to which Condos refers only in a footnote to the second to last sentence of his conclusion - or with other recent works that make use of the term and concept.

The emphasis on anxieties, consequently, works only partially throughout the book. In chapter one, for instance, it leads to a rather reductionist narration of a century of imperial expansion in South Asia, and also in chapter two the argued correlation between annexed Punjab's pacification and colonial anxieties is not completely convincing. Chapters one and two are not the most original ones and, stripped of the 'anxiety angle', remain competent syntheses of rather broad topics that have been dealt with before. It is in the following three chapters where the study really shines. Delving deep into archival material allows Condos to trace official feelings, discussions and policies in often complex and interwoven ways. Here, Condos examines crucial moments and developments of the colonial experience that have hitherto not been sufficiently considered. In particular, chapters four and five have to be highlighted as they very convincingly show one of the main arguments of the book: that policies in the Indian North West had a significant impact on discussions and actual legislation in the centre.

While Condos intends primarily to show the vulnerability of the empire, he also sees his thesis as part of a broader historiographical project that tries to overcome the popular myth that British rule in India was 'a 
powerful, confident, and nearly indomitable force' (p. 10). However, whereas the book undoubtedly succeeds in giving the reader an impression of the sense of vulnerability British officials in the subcontinent may have felt, the study hardly qualifies as a corrective to the narrative of an omnipotent British rule in South Asia. On the contrary, one is tempted to say that the book's focus on matters of governance and legislation even perpetuates such accounts. While the authoritarian nature of rule in Punjab is explained as driven by insecurities, its reach and capacity is hardly questioned in The Insecurity State. As a related issue, the extremely narrow focus on British high-officials and decision-makers and the omission of Indian figures in the picture Condos draws have to be mentioned. While one might argue that this is due to the purview of the study, it is still somewhat disconcerting that the book is almost completely void of any native, nonBritish voice or agency. As a whole, Condos's work (intentionally or unintentionally) gives the reader the same feeling that he attributes to his historical objects of study: one of isolation where interaction between Anglo-India and the native population hardly occurs and the Indian inhabitants of the subcontinent only appear as 'the other'; an anonymous and potentially dangerous mass. Such an approach runs the risk of reducing the history of imperialism to a history of the imperialists. Of course, it is not completely fair to criticise this absence in a study specifically on colonial governance and official policies, and there was undoubtedly much effort and concern among Anglo-Indian society to isolate itself from the native population. But still, one wonders whether there would not have been ways to draw a picture that is not that much a reflection of the sentiments of the book's objects of study, but that - such as, for an example, C. A. Bayly's famous Empire and Information (1) that deals with similar topics of imperial (in)security - tries to consider the complexities and nuances of the colonial situation and the role and agency of multifariously motivated cooperating, contesting or mediating Indian figures.

Leaving aside what the book misses, there is much to be praised that The Insecurity State provides. While it hardly questions the power of the colonial state, it keeps away from describing it as a triumphant success story. Condos manages to contribute a comprehensive and substantiated explanation of the causes of colonial violence without leaving the impression of absolving the historical figures of imperialism of their often atrocious actions. Convincingly conveying the state of fear many British, especially frontier officials lived in, the study reveals the various insecurities that underlay the ostensible imperial bravado. It shows that particularly Punjab and its authoritarian school of administration was a producer and reservoir of colonial anxieties and 'a laboratory for a number of practices and ideas that were later exported to the wider empire' (p. 19) and ironically, although supposed to be means for the protection of colonial security, often fuelled even more concerns. Condos succeeds in reconciling the administrative history of this frontier region with the broader history of British India and the Empire without falling for a narrative of exceptionalism that has hitherto informed many works on the history of Punjab.

Written in an engaging prose and supplemented with occasional evocative narrative interludes and references to current affairs in today's India and Pakistan, The Insecurity State provides us with a thoughtprovoking and profound analysis of colonial insecurities, violence and legislation. While it occasionally suffers from an over-use of its under-theorized 'anxiety' concept, it offers a fresh angle on governance in (mostly early) colonial Punjab and British India and on the inherent contradiction between imperial power and vulnerability.

\section{Notes}

1. Christopher A. Bayly, Empire and Information: Intelligence Gathering and Social Communication in India, 1780-1870 (Cambridge, 1997).Back to (1)

\section{Other reviews:}

Historian

https://projects.history.qmul.ac.uk/thehistorian/2017/08/15/take-five-with-mark-condos/ [2]

Source URL:https://reviews.history.ac.uk/review/2228

\section{Links}


[1] https://reviews.history.ac.uk/item/291916 [2]

https://projects.history.qmul.ac.uk/thehistorian/2017/08/15/take-five-with-mark-condos/ 